Archived version from NCDOCKS Institutional Repository http://libres.uncg.edu/ir/asu/

\title{
Appalachỉan
}

B O O N E, N O R T H C A R O L I N A

\section{The Roles Of Social Entrepreneurs In Rural Destination Development}

\author{
By: Ziene Mottiar, Karla Boluk, and Carol Kline
}

\begin{abstract}
This paper seeks to explore how social entrepreneurs are relevant to our consideration of rural destination development. While many peripheral rural areas face significant challenges in terms of sustaining communities and attracting tourists it is often social entrepreneurs, as much as traditional entrepreneurs, who are involved in developing new ideas, new products and activities, and envisioning a future for the area. This study, which is based on case studies resulting from nine semi-structured interviews carried out in rural areas in Ireland, South Africa and USA, identifies key roles that social entrepreneurs play in terms of rural destination development; namely that of an opportunist, catalyst, and network architect, and this is used to build a theoretical framework within which SEs can be analyzed.
\end{abstract}

Mottiar, Z., et al. (2018). "The roles of social entrepreneurs in rural destination development." Annals of Tourism Research 68: 77-88. https://doi.org/10.1016/j.annals.2017.12.001. Publisher version of record available at: https://www.sciencedirect.com/science/article/pii/S0160738317301561 


\section{The roles of social entrepreneurs in rural destination development Ziene Mottiar ${ }^{\mathrm{a}}$, Karla Boluk ${ }^{\mathrm{b}}$, Carol Kline ${ }^{\mathrm{c}, *}$ \\ ${ }^{a}$ School of Hospitality Management and Tourism, Dublin Institute of Technology, Cathal Brugha Street, Dublin 1, Ireland \\ ${ }^{\mathrm{b}}$ Faculty of Applied Health Sciences, Department of Recreation and Leisure Studies, University of Waterloo, 200 University Avenue West, Waterloo, \\ Ontario N2L 3G1, Canada \\ ${ }^{\mathrm{c}}$ Hospitality and Tourism Management, Appalachian State University, 4078 Peacock Hall, Boone, NC 28608, United States}

\section{A R T I C L E I N F O}

\section{Keywords:}

Social entrepreneur

Rural tourism

Rural destination development

Tourism potential

Network architect

\begin{abstract}
A B S T R A C T
This paper seeks to explore how social entrepreneurs are relevant to our consideration of rural destination development. While many peripheral rural areas face significant challenges in terms of sustaining communities and attracting tourists it is often social entrepreneurs, as much as traditional entrepreneurs, who are involved in developing new ideas, new products and activities, and envisioning a future for the area. This study, which is based on case studies resulting from nine semi-structured interviews carried out in rural areas in Ireland, South Africa and USA, identifies key roles that social entrepreneurs play in terms of rural destination development; namely that of an opportunist, catalyst, and network architect, and this is used to build a theoretical framework within which SEs can be analyzed.
\end{abstract}

\section{Introduction}

The focus of this paper is to enhance our understanding of the key roles social entrepreneurs (SEs) play in rural destination development and to develop a new theoretical framework as the foundation of further research in this area. As Jaafar and Rasoolimanesh (2015) note rural tourism represents a tool for rural revitalization. SEs can influence the development of rural tourism; however, literature documenting the roles they play is lacking, posing a gap in understanding the ways rural tourism is developed. Examining the roles of SEs in tourism destinations sheds light on the engagement of entrepreneurs who are motivated not only by profit, but also by social objectives. This type of academic engagement reflects pragmatic changes that are evident in rural tourism destinations.

This paper addresses gaps in our understanding of the roles SEs play in rural destination development. This was achieved through our cross-case analysis from Ireland, South Africa and USA. The objectives of the paper are four-fold. Firstly to identify if there are commonalities in terms of the roles that SEs play in rural tourism destinations, secondly to identify the roles that are played by SEs in rural tourism destinations, thirdly to examine how these roles are connected and fourthly to begin to build a framework within which the role of SEs can be analyzed.... Combining findings from three geographically diverse contexts, our paper provides rich insight into the role of SEs as opportunists, catalysts and network architects in rural destinations and suggests that our rural tourism lens needs to adjust from focusing primarily on the role of communities, policy makers, and to a lesser extent entrepreneurs, to encompass this new stakeholder. Doing so will provide an opportunity to push existing boundaries and consider the role of SEs in rural tourism development. The next section reviews the concept of entrepreneurs and SEs in tourism, on which this paper is based.

\footnotetext{
Corresponding author.

E-mail address: klinecs@appstate.edu (C. Kline).
} 
Ritchie and Crouch (2003, p. 140) highlight in their destination competitiveness model that entrepreneurs and small businesses are of "fundamental importance to the development of tourism as an industry". While the tourism industry is mainly comprised of small businesses (Lashley \& Rowson, 2010), exploring their impact is absent in the literature (Power, Di Domenico, \& Miller, 2017). Specifically, small businesses may cultivate strong social capital as they may act as a link between the local community and the tourism industry (Shaw \& Williams, 1998). However, the tourism literature, according to Koh and Hatten (2002), has 'overlooked' the tourism entrepreneur as a player in tourism development. Recently, some scholars note the important role that entrepreneurs may play within destinations. For example, Komppula (2014, p. 361) concludes that "without innovative committed, and risk-taking entrepreneurs no destination will flourish". Ryan, Mottiar, and Quinn (2012) demonstrate that the influence of entrepreneurs may continue long after the original entrepreneur is involved through the development of an environment in which entrepreneurship is encouraged and supported.

Despite the importance of entrepreneurs to destination development, the various roles they play requires investigation to shed light on how social objectives are achieved. Perhaps an obvious role is that their efforts, through product development, may attract tourists to destinations. However, the contributions of multiple entrepreneurs are less obvious and can have a combined effect, which is often greater than the impact on their own individual firms and exhibited through the formation of networks contributing to destination development (e.g., Beritelli, 2011; Pavlovich, 2003; Tinsley \& Lynch, 2007). Russell and Faulkner (2004) examine tourism entrepreneurship within the framework of chaos theory and state that entrepreneurs "play a primary role both as chaosmakers and as initiators of adaptive responses to chaos induced by external events" (2004, p. 556). Entrepreneurs also act as leaders within the destination, often developing a long term vision (Ryan et al., 2012), being innovative (Weiermair, Keller, Pechlaner, \& Go, 2010), and identifying opportunities (Johns \& Mattson, 2005). It is also notable that local social situations and environments may affect entrepreneurial strategies (Bosworth \& Farrell, 2011; Kline \& Milburn, 2010; Mottiar, 2015). As such, entrepreneurs tend to be deeply connected to the rural economy and the community, leading us to further consider the entrepreneur community connection and in particular, the role of SEs.

\section{Social entrepreneurs and tourism}

The existing literature echos several dominant dimensions of entrepreneurship including autonomy, innovativeness, risk-taking, proactiveness, and competitive aggressiveness (Covin \& Slevin, 1989). Dollinger (2008, p. 10) defines entrepreneurship as "the control and deployment of resources to create an innovative economic organization for the purpose of gain or growth under conditions of risk and uncertainty". While some literature (e.g., Licht \& Siegel, 2006) implies the social agency of entrepreneurs such interests seem to be environmentally sensitive (e.g., heightened agency in developing economies) and thus not indicative of entrepreneurs generally. Indeed, the literature is dominated by the supposition that traditional entrepreneurs are almost exclusively motivated by self-interest; specifically in regard to maximizing profit, and an individual's personal utility (Miller, Grimes, McMullen, \& Vogus, 2012). However, recently SEs, who are distinctively motivated by social objectives have been identified.

Although scholars have yet to determine one single definition, it is accepted that social entrepreneurship (SE) is "an innovative, social value-creating activity, that can occur within or across the non-profit, business or government sector" (Austin, Stevenson, \& Wei-Skillern, 2006, p. 2). As such, SEs may consciously pursue social and/or economic objectives. Dees (1998, p. 4) suggests SEs "play the role of change agents" [...] "by creat[ing] and sustain[ing] social value", "relentlessly pursuing new opportunities" serving a social mission, continually innovating, adapting and learning, and "exhibiting heightened accountability". The range of explanations in consideration of who social entrepreneurs are, how they are motivated, and what they are capable of suggests that research contributing to a typology of SEs may aid in our understanding.

Enhancing well-being (Perrini, 2006) via focusing on social agency, and accountability is what distinguishes SEs from traditional entrepreneurs. Furthermore definitions of success are variant, traditional entrepreneurs seek profit maximization whereas SEs prioritize social impact and draw on revenue streams in order to ensure financial sustainability. Examples of social entrepreneurs spanning environmental, and/or social interests include Cicely Saunders who started the hospice movement, and Mohammad Yunus who started micro-financing to a group of women in a Bangladesh. The purpose of this paper is to explore the roles of SEs in driving rural destination development, and where possible, discover patterns toward the development of new frameworks or theory.

Different types of SEs have been identified in the literature including resourceful key actors, heroic individuals (Nicholls, 2010), and those interested in "put[ing] something back' into society" (Thompson, 2002, p. 414), aiming to create social change (Dees, 1998). Personal motivations of SEs reflect one's "voyage of self-discovery and [...] drive by a cause (Thompson, 2002, p. 414). The primary focus of SEs to make a social contribution perhaps explains the positive light in which the research presents these individuals. SEs encompass a variety of individuals with different backgrounds and in some cases, the social objectives are their only motivation, whereas in others, such objectives parallel profit interests. The shared commonality is a desire to achieve social objectives.

Research on SEs has gained traction among a variety of business fields yet, interest among tourism scholars has been slow to develop. The insurmountable behaviours and practices in the tourism industry globally highlight the imperative for sustainability thinking (Boluk, Cavaliere, \& Higgins-Desbiolles, 2017). Sustainability discussions in tourism highlight opportunities for considering the role of SEs (Ergul \& Johnson, 2011). A SE keyword search carried out in July 2017 among top tourism journals revealed only one publication in Annals of Tourism Research (Kimbu \& Ngoasong, 2016) and Tourism Management (Altinay, Sigala, \& Waligo, 2016). Kimbu and Ngoasong's (2016) research details the critical role of women SEs in Cameroon, who combine social transformation and commercial goals while promoting local development. Altinay et al.'s (2016) research used Guludo Beach Lodge in Mozambique as a 
case study, identifying strategies associated with resource mobilization leading to social value creation, including stakeholder involvement and collaboration, relationship development, and local community empowerment.

Recent interest in SE and tourism is evidenced in a special issue in the International Journal of Contemporary Hospitality Management (Okumus, Chen, Barber, Chan, \& Legrand, 2016) and an edited volume on Social Entrepreneurship and Tourism (Sheldon \& Daniele, 2017). To date, much of the emphasis has been on identifying the motivations of SEs (e.g., Boluk \& Mottiar, 2014), their behavioral traits (e.g., Vasakarla, 2008), and their involvement in social and economic development (e.g., Alegre \& BerbegalMirabent, 2016; Boluk, 2011). Recently, Sigala's (2016) research, focused on the generation of social value in SE, determining three capabilities: network structure, market practices, and market pictures. In order to further and deepen our understanding of SEs it is important to consider how SEs affect our consideration of tourism (Mottiar \& Boluk, 2017). Specifically, our research employs a comparative cross-case analysis to explore the roles of SEs in achieving social objectives in rural development. According to Ketokivi and Choi (2014, p. 232) in their essay "Renaissance of case research as a scientific method," three different methodological approaches to case research exist: theory generation, theory testing, and theory elaboration. In this regard, we are engaged in early theory generation regarding rural SEs.

\section{Materials and methods}

\section{Overview ofmethods}

The methodological approach adopted relies on cross-case analysis of qualitative research that was undertaken in three separate case studies. The geographical reach of the data provides insights into experiences in very different contexts, and yet identifies similarities that offer understanding into the roles SEs can adopt. The three destinations under consideration include: Kerry in the west of Ireland, the Eastern Cape in South Africa, and Chatham County in North Carolina, USA. All three locations represent rural areas that are utilising tourism as a way of leveraging growth and sustainability for local communities and economies.

Within the social sciences, cross-case analysis or multiple case analysis has been used since the 1960s as an approach for building theory. Employing the data from cases, along with previous literature and researcher experience, allows for the development of a testable, reliable, and valid theory. Eisenhardt and Graebner (2007) note: "A major reason for the popularity and relevance of theory building from case studies is that it is one of the best (if not the best) bridges from rich qualitative evidence to mainstream deductive research. Its emphasis on developing constructs, measures, and testable theoretical propositions makes inductive case research consistent with the emphasis on testable theory within mainstream deductive research" (p. 25).

Cross-case analysis has been employed in tourism and hospitality studies, but not widely. Andersson, Carlsen, and Getz (2002) performed a cross-case analysis of family business goals in hospitality and tourism in Australia, Canada, and Sweden. Their study also explored aspects of rural tourism entrepreneurs, but focused on the family unit, and in particular, family business goals. This method revealed "striking similarities" regarding "lifestyle considerations, location preferences, and uncertainty over disposition of the businesses" (Andersson et al., 2002, p. 89). In 2014, Ainley and Kline used interpretative research approaches to explore agritourism among Canadian and American operators. The authors noted that "discussions between [them] provided additional depth to each of their studies" and "the reflexive collaboration was a significant factor in supporting what each author was finding in their own individual study" (p. 410). Hegarty and Przezborska (2005) compared rural tourism cases in Ireland and Poland to outline the similarities and regional differences in rural development policy, available resources, and operator motivations. These collaborations across borders provide insight into patterns and depth to understanding differences within complex development scenarios.

\section{Overview of cases}

The first case is in County Kerry in the South West of Ireland. The fifth largest County in Ireland, Kerry has a population of 1,47,554, (Central Statistics Office [CSO], 2016). County Kerry is reliant on tourism and receives the highest number of visitors in Ireland after the cities of Dublin, Cork, and Galway. While the number of tourists visiting Kerry remains high, and the town of Killarney is a key attraction, the other more rural villages in the county rely on innovative strategies to increase their attractiveness. This study focuses on two such villages; the first is Ballydavid, which has a population of 433 people (CSO, 2016). This small village is in a Gaeltacht area (mainly Irish-speaking area). Key attractions are 'uncommercialised local culture' (http:/ / www.dingle-peninsula. $\mathrm{ie/ballydavid.html),} \mathrm{walking} \mathrm{areas,} \mathrm{and} \mathrm{beaches.} \mathrm{Killorglin} \mathrm{is} \mathrm{a} \mathrm{small} \mathrm{village} \mathrm{with} \mathrm{a} \mathrm{population} \mathrm{of} 4373$ people (CSO, 2016). It is famous for its 400 year old annual Puck Fair held in August whereby a goat is crowned king and reigns over the village for three days. The fair includes music, storytelling, dancing, a horse show, and family activities, and is used as a base for tourists who are visiting the Ring of Kerry scenic driving route (http:/ / www.kerryguide.com/killorglin/). This case focuses on three SEs within these two villages who have used entrepreneurial skills to enhance community cohesion and an entrepreneurial approach to address a local issue. Their clear social objectives have had an impact on tourism in the area. Their roles became apparent in research conducted to investigate the social impacts of The Gathering (Mottiar, Quinn, \& Ryan, 2014), a national tourism-led initiative that took place during the recession in 2013 and was aimed at encouraging Irish diaspora to visit Ireland.

The second case focuses on three tourism SEs along the Eastern Cape of South Africa and affiliated with Fair Trade Tourism (FTT), a non-profit organization that emerged in 2002 with the purpose of promoting equitable and sustainable tourism development in South Africa, Mozambique, and Madagascar (Boluk, 2015). Specifically, FTT businesses (including lodges, backpackers, hostels, tourism activities such as cruises, wildlife sanctuaries, paragliding, sanctuary/canopy tours, shark projects, golf clubs, educational tours) focus on the inclusion of marginalized communities previously disadvantaged during the apartheid rule from 1948 to 1994 , 
prioritizing shared decision-making and black empowerment. The assets of the Eastern Cape include two major airports, agricultural farming land, private game reserves and all-terrain trails, more than a dozen national parks, numerous beaches, and access to the ocean appealing for adventure tourism activities such as surfing. Case data were purposively collected between May 2008 and March 2013 involving two field visits to the destination. Three tourism SEs are highlighted from two accommodation providers Bulungula Lodge and Coffee Shack, and one tour company Calabash Tours; each are focussed on the social objective of effecting societal change in terms of exclusion and marginalization.

The third case is based upon Chatham County, a central county in North Carolina, located on the east coast of the USA. Chatham County is located within an hour's drive of cities that represent approximately one million in population; however, the two largest within the county have populations of $\sim 8000$ (Pittsboro) and $\sim 4000$ (Siler City) (Chatham County, n.d.). The Pittsboro-Siler City Convention and Visitors Bureau [PSCCVB] is a one-person office, run by its founding director, Neha Shah. The county's assets include biking and hiking trails, birding opportunities, local eateries and pubs, agritourism farms and public gardens, historic sites, a vibrant arts scene, the Abundance North Carolina multi-use complex comprised of micro-enterprises, farmland, small meeting space and the non-profit offices that coordinate the property; and Fearrington Village, a Relais \& Chateaux resort and spa (PSCCVB, n.d.). The Chatham case study focuses on culinary tourism and the SEs who have worked to incrementally build this brand. Case data were collected on an on-going basis from June 2011 to June 2016 as the destination evolved. SE's from three organizations will be highlighted: the PSCCVB, Abundance North Carolina (ANC), and Angelina's Kitchen. The leaders of these organizations (Neha, Tami, and Angelina, respectively) have been instrumental in addressing social issues by calling attention to the needs of the community, namely general economic enhancement in the small business sector, assistance for small farmers, access to healthy food options, environmental protection amid growing development, and community initiatives that showcase the culture and personality of Chatham.

The three case studies relied on qualitative data drawn from in-depth semi-structured interviews (Table 1), as well as archival documents, websites, and observations. The data were originally collected for separate projects by independent researchers; however, each of the projects focused on entrepreneurs and entrepreneurial activity within community-based tourism destinations. Each sample was purposively selected based on our research intent - to identify the roles of SEs within rural destination development therefore providing an opportunity to compare and contrast the roles SEs played in three settings. Data from a total of 9 informants supports the insights within the study. There are multiple levels of analysis within the current study: destination (community), organization (firm), and individual. While there is considerable cultural variation within the tourism product mix at each destination, the locally-controlled, community-focused experiences crafted at each provide a thread of continuity among the three cases.

\section{Case analysis}

Ketokivi and Choi (2014, p. 234) remind us that "the premise in theory-generating case research is that in the context of the specific research question and empirical setting, explanation (theory) derives from exploration (analysis)." We began the analysis with each researcher extracting themes from her own study and subsequently, reflexively discussing the themes with one another. This stage of the research was addressing our first objective to examine if there were similarities in terms of the roles of SEs in different rural tourism destinations. As we combed through our transcripts, we looked for roles, functions, activities, motivations, and behaviors undertaken to develop tourism and/or to generate positive externalities for the community or for community member groups. As discussed above, the literature on entrepreneurs and SEs is diverse - and addresses each of these five broad areas. By exploring our transcripts with these elements in mind, we were able to identify that there were commonalities and we then created individual themes that were sharpened and clarified into "roles" to address the second research objective. These five elements were used to frame our investigation within and across the cases and led to the framework we have developed in Fig. 1. Our initial

Table 1

Summary of data collection methods and outputs.

\begin{tabular}{|c|c|c|c|}
\hline & Co Kerry & Eastern Cape & Chatham County \\
\hline Study period & 2013-2016 & 2008-2013 & 2011-2016 \\
\hline Purpose of original study & $\begin{array}{l}\text { To examine the social and community } \\
\text { impact of The Gathering }\end{array}$ & $\begin{array}{l}\text { To investigate the meaning and } \\
\text { discourse associated with Fair } \\
\text { Trade Tourism }\end{array}$ & $\begin{array}{l}\text { Exploration of entrepreneurial } \\
\text { ecosystem }\end{array}$ \\
\hline Original number of interviews & $\begin{array}{l}\text { Three focus groups ( } 4-9 \text { participants), ten } \\
\text { key informant interviews and surveys of } \\
73 \text { event organisers and } 251 \text { community } \\
\text { members }\end{array}$ & $\begin{array}{l}\text { Three along the Eastern Cape, } \\
\text { nineteen outside of the province }\end{array}$ & $\begin{array}{l}\text { Two within Chatham County; } \\
\text { ten outside of the county }\end{array}$ \\
\hline Length of interviews & $30-60 \mathrm{~min}$ & Approximately $1.5 \mathrm{~h}$ & $30-60 \mathrm{~min}$ \\
\hline $\begin{array}{l}\text { Resulting number of transcribed } \\
\text { pages/notes relative to } \\
\text { current study }\end{array}$ & 19 pages & 70 pages & 18 pages \\
\hline $\begin{array}{l}\text { Data gathered or updated for } \\
\text { current study }\end{array}$ & 5 interviews & Review of current websites & Review of current websites \\
\hline $\begin{array}{l}\text { Informants in the current study } \\
\text { (some are pseudonyms) }\end{array}$ & John, Mary, Brian & Paul, David, Dave & Neha, Tami, Angelina \\
\hline
\end{tabular}




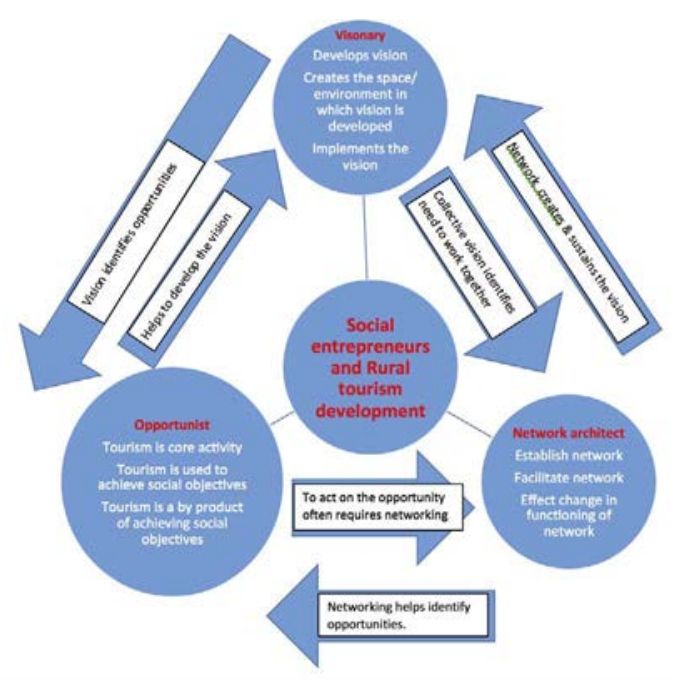

Fig. 1. The Roles of Tourism Social Entrepreneurs in Rural Destination Development.

discussions on themes, issues, and individual cases took place via Skype and email over the course of 14 weeks.

This process led to the development of a conceptual framework that included two roles identified within the collective data. Our knowledge of the tourism entrepreneurs' literature in particular also informed this framework. As we dissected the data to analyze these roles in the individual cases, an additional role was revealed in one case and then identified in the others. Following extensive debate consensus was then found regarding this construct. We then engaged in an iterative process of comparing constructs with data. This was performed with simultaneous conversations via email but also within a Google document in which the findings were generated collectively, commented upon, and cross-edited by all three researchers. Shorter comments were handled within the document, while longer "conversations" were held over email. We took care to discuss data of "atypicality", as well as consensus (Stake, 2005). In this way, we sharpened the constructs by (1) refining the definition of the construct and (2) building evidence that supports the construct in each case (Eisenhardt, 1989).

The cross-site tactics of analysis included reviewing each other's texts, questioning one another about each other's data, reinterpreting one another's informants' intentions, and providing insights into each other's data from an "external" perspective. After approximately 20 weeks of this, it was clear that our constructs were sound; however, the amount of data was not manageable. The unanimous decision was made to reduce the number of informants portrayed within this narrative to the nine included here, which highlight a broad swath of content across the three destinations, that illustrate the three identified roles of SE in rural destinations. The inductive nature of this research meant that over the total 15 month period of extensive and continual analysis and cross comparison, the constructs underpinning the roles of SEs were not only identified but as Eisenhardt (1989) noted, the cross-case approach has resulted in insightful findings that inform our understanding and form the basis of theory building on this topic.

\section{Findings and analysis}

This research identifies three key roles played by SEs within the development of rural destinations. In each of the three cases the SEs have specific social objectives, in some cases they relate to tourism but in others achieving these objectives have had an impact on the rural tourism destination. These SEs are the people who often identify tourism opportunity in the first instance, play a key part in advancing local networks, and develop common goals and visions among the local community. Within the remaining space, we demonstrate how each case from different destinations supports the three constructs. As Eisenhardt and Graebner (2007, p. 29) warned "the challenge in multiple-case research is to stay within spatial constraints while also conveying both the emergent theory that is the research objective and the rich empirical evidence that supports the theory."

\section{Opportunist}

Our data collectively revealed that SEs act as opportunists, as they often identify the potential that tourism has for a rural destination. For many rural economies primarily based on agriculture, the move to tourism is often a result of the difficulties in sustaining communities on agriculture alone. In peripheral areas, geographic isolation compounds such difficulties, posing a challenge in the development of alternative industries. The first step in the shift towards tourism can be taken at an individual level as business people and new entrepreneurs move into this space, at a policy level as local government and tourism bodies implement strategies to encourage the development of tourism, and at a destination or community level as individuals identify the potential (Russell \& Faulkner, 2004; Wilson, Fesenmaier, Fesenmaier, \& Van Es, 2001). Across the three cases, it is evident that the SEs identify opportunities that tourism could create, both in terms of the destination and achieving their own social objectives.

The omnipresence of poverty along the Eastern Cape provides a practical backdrop for innovative responses to addressing scarcity via tourism. All of the South African informants highlighted an inability to disengage with inequality in South Africa. A realization of 
the SE role emerged from a combination of travelling, activism, and political engagement. Demonstrable compassion was articulated by one rural tourism SE when he said in reference to responsible tourism "this is something that everyone should be doing, it's just a natural thing" (David, Coffee Shack). Building on a natural inclination to engage with poverty, Paul identified a resolve for "creating a tourism culture in the township to volunteer". Specifically, Paul identified ways to meaningfully embed tourism within the community. For example, "We want to make sure we can serve the communities the best way we can". One way of serving the communities Paul put forth was the introduction of volunteer experiences:

We deal with a lot of people who are 50 plus, and they want to come and work for a month [...] from 8 to 4 [...] the sense of reward they get from this, they could have taken a cruise for the same amount of money [...] they say that they learn so much from the communities (Paul, Calabash Tours).

Calabash was the first business certified as a Fair Trade volunteer tourism business in 2006, with the primary concern to make tourism work for the local community, following the interest visitors had in making a contribution to the township. Similar sentiments were shared among the other South African SEs in terms of the unique opportunity their businesses offered visitors with an interest in experiencing a responsible community based tourism business model which encompassed "70-80\% of the business" (at Bulungula Lodge). Further to providing socially responsible experiences, David articulated the potential of attracting tourists to their rural village as a way to gain perspective and "bring about deeper meaning" (Coffee Shack). Accordingly, there was an understanding that attracting travelers to their remote locations provided an experience that western travelers were seeking. Thus, their geographic context could be regarded as an opportunity that the SEs recognized in terms of tourism potential.

In many rural areas, local events are organized with the social objective of creating community cohesion but such events may also attract tourists. An example is The Spud Mór Festival, which has operated since 2010 in Ballydavid, an extremely rural area in west Co. Kerry. This is a potato growing competition started by John in 2009 that has grown each year and now includes eight communities. Each has its own local organization and the winners from these local competitions, which usually occur over 3-5 weeks during the summer, then become finalists in Ballydavid. The focus on social objectives is clear, according to John:

the goal is very basic, it is to have something to get local communities more outward looking and have a period mid-summer when they mix with people they may not have seen since this time last year. It also encourages people to grow [food] and to become more health conscious.

In 2013 it "became quite a different festival" as the committee decided to see how "we could make the festival available to strangers [...] which wasn't on our agenda before". This was a deliberate decision as the festival became part of The Gathering, with the key objective of attracting more tourists to the area. At this point, John said

we reviewed what we had and what we could make of it, a more formal committee was established, planning for the event began earlier and the events were scheduled within a single week to make it more attractive for visitors. Furthermore, additional events were added to the program.

This shows an identification of the tourism potential of what heretofore had been a local community event. Interestingly, John suggested that this resulted in additional work and associated costs, and they have not taken this approach in subsequent years.

As John clearly stated, An Spud Mor is "very much targeted at local communities - a byproduct is the impact on tourism", nonetheless, the festival is gaining significant media attention. Each year there has been a media presence with RTE (Ireland's national broadcaster), BBC, BBC Good Food and a US food channel all creating programs and features on the festival. Such marketing "has a huge impact on tourism" (John). The local tourist office also promotes the festival to visitors in the area. As the tourist information officer notes, it is a local festival but "it is unique and gives people an insight into what really goes on here" and tourists like that. It is clear that the SE mission is not to create a tourism product, but by attracting national and international attention, there is an impact both in terms of strengthening sense of community and connectedness and in terms of enhancing the tourist experience and establishing the area as a potential destination in the minds of an international audience.

In Chatham County, Neha, the Director of PSCCVB, has guided would-be business owners and tourism entrepreneurs to develop experiences and services that correspond with the county's identity. Accordingly, she has witnessed incredible growth in the diversity of her tourism product mix. She notes "the last decade has shown increased opportunities for farms to offer more product to aspiring and established chefs seeking to appeal to the high demand for local food, fresh ingredients, and creative cuisines". As the sole person responsible for the tourism office, Neha has been in the unique position to understand the county's tourism potential, identity opportunities, formulate strategies to differentiate it from competitors, and creatively draw on the pockets of burgeoning innovation in the county to develop 'product' and build the county's brand. Fifteen years ago, Neha recognized the potential in the county's raw assets, and unlike some of her peers in other rural areas of North Carolina who focus only on the marketing of finished product, she builds momentum by working with stakeholders one by one, helping them to develop their niche in the larger vision.

Angelina is founder of Angelina's Kitchen, a farm-to-table restaurant that serves healthy, affordable, seasonal, and local food to residents and visitors to Chatham County; she also caters events both inside and outside of the county. Angelina noticed that the farmers in the county were growing exceptional product but the residents did not "know how to use food-pumpkins even are 'on the edge' and can be used [in dishes] beyond pumpkin pie." She went on: "so the collards, sensopai, and other produce-people were asking about how to use these, so I decided I would cook for everyone (residents and tourists)...I'll open a restaurant!" Angelina started Angelina's Kitchen as a take-out and catering operation in early 2009 and transitioned to incorporate a sit-down space two years later. Angelina's and John's intent includes enhancing public health and farmers' livelihoods through their work:

We have a social bottom line-we're contributing to the community and I've been doing cooking classes with kids and adults [...] we pay 
extra for the environmental products. It's a green practice, of many, that we employ. We have all eco-friendly forks, spoons, knives [...] We compost, feed the pigs with our stuff. Kids get involved and it goes from there-in the schools, at home, etc.

The different cases similarly reveal that SEs actively identify tourism opportunities and, in some cases, contribute to the growth of tourism in their areas. Nonetheless, this role is complex. In the case of Paul in South Africa, attracting tourists via volunteering was clearly part of the mission of his entrepreneurial activities, whereas for John in Ireland and for Angelina in the USA, tourism was simply a by-product of his/her social objective, which was to facilitate community interaction by encouraging people to grow their own food (for John) and enjoy the bounty of locally grown produce (for Angelina), rather than something they initially set out to achieve. For Neha, in Chatham, she did not create a product herself, but her actions encouraged and helped others in the destination to identify tourism opportunities. Accordingly, the cases reveal that the role SE's play in terms of identifying tourism potential can range from being the tourism provider, to accidently attracting tourists as a result of their activities, to highlighting tourism opportunities that others may avail of. It is important to note that we do not argue that these examples are exhaustive; it is likely that research in other destinations would identify other ways that this role is played by SEs. However, we do argue that SEs do have a role in identifying opportunities and contributing to tourism potential in destinations.

\section{Catalyst}

As Haven-Tang and Jones (2012, p. 28) note, "rural tourism destinations have often developed through disparate means, lacking a coherent rural destination development strategy". They also note the importance of the involvement of local communities "to drive these policies forward" and increase the chance of success, and in this regard, highlight the importance of the nexus between leadership and followership. The catalyst for developing a vision may result from, for example, a national economic crisis (Gorman \& Mottiar, 2015), a funding scheme (Haven-Tang \& Jones, 2012), concerns for enhanced equity and community involvement (Boluk, 2011), or the decline of a local industry on which the community was dependent (Jordan, 2015). McGehee, Knollenberg, and Komoowski (2015) also observe the important role of leaders in rural tourism development and the impact that their bridging and bonding social capital attributes can have on the destination. In the cases, we also see that SEs play a role in terms of acting as catalysts to develop a collective vision in rural tourism destinations. Notably, none of the visions developed by SEs in our cases were carried out in isolation; rather, each SE plays a role in facilitating the development and/or implementation of a collective vision.

For some of the SEs in South Africa, their certification via FTT provided complementary alignment for what they considered possible in South Africa's democracy post-apartheid. Specifically, the principles of fair trade around fair wages, working conditions, distribution of benefits, equality, democracy and respect for cultures seemed to coalescence into a collective vision for an improved and integrated South Africa reliant on mutual support. At the local level, this vision was implemented by the SE who determined a fundamental goal and take home message for those visiting. For example, oneSE stated: “A place like Bulungula really does benefit South Africans more than anyone [...] and hopefully gives people a little taste of what is possible in terms of you know just getting along" (Dave, Bulungula). This same SE highlighted an aligned vision of FTT: "there is a bigger mission going on here [...] focusing on responsible community based tourism [...] fair trade is becoming the label that defines responsible travel [...] and businesses that are accredited run on those principles." Solidifying one's vision and commitment to the guiding principles driving FTT was articulated by another SE when he said "sometimes being part of organizations like this is to be part of the bigger picture" (David, Coffee Shack). As such, being part of a collective, with a broader mission to contribute to and create social change was important. However, it was also evident that improved efforts were required by FTT to ensure that South African stakeholders (such as the government) werefamiliar with the brand so that the valuecreated was understood and supported, enhancing value possibilities.

Further to the primary vision of FTT supporting the collective interests of the SEs, Paul from Calabash highlighted the ability for FTT to strategize: "they are sharp in terms of picking up on what needs to happen next." He further stated:

The goal of FTT for the next few years is to engage more with transformation issues outside of certification, the certification is established [...] and now they are going to get involved in other projects that will help with establishing community owned tourism products. This is what we are doing. This is what other businesses need to do. FTT gets it.

As exemplified in the above quotations, the South African SEs highlighted their mutual interests in leading by example, and demonstrating what is possible in the country's new democracy. The goals of each SE aligned with the overarching vision of FTT, which created a space for mutual engagement and opportunity to align visionary sustainability interests. Furthermore, the support of a progressive organization such as FTT has supported the change making capability of the three SEs. Thus, the examples demonstrate the important role individual SEs may play in acting as a catalyst and giving life to a collective vision.

In Chatham County, the very nature of Neha's job puts her at the centre of economic and community development activity. Working together with other county government employees, private businesses, non-profit organizations, and elected officials, she cultivates a common understanding of future tourism directions. As societal taste shifts and trends emerge, she determines ways to align the goals of tourism stakeholders with budding possibilities. Neha explains

Since its inception, the PSCCVB has recognized the value of the agricultural landscape of the county. The significance is vast, the ongoing relationship with local farms, farmers, agribusiness connects of all realms simultaneously with new and experienced chefs, caterers, food and drink entrepreneurs. The best outcome must come from working with as many of these groups and individuals, one-on-one and in joint collaborations-marketing the individual business, working with the food council, creating trails to link complementary businesses, and innovating new ventures when appropriate, which is often in this growing environment.

Additional food-based growth was spurred by the non-profit organization ANC, which was founded to educate the public on why 
community efforts focused on sustainability were critical to the success of a rural region (ANC, n.d.). The name of the organization is derived from the Theory of Abundance, which states "that there is enough of everything in this world for all of us, if we are willing to share"; ANC's programs and partners incorporate this outlook into each of their initiatives:

what we really need, in order to tackle the problems of today, is not to focus just on protecting our own self-interests, coming from a fearbased outlook, but instead to keep our eyes and minds open, and to consider how we can pool our talents and resources, work together, brainstorm and come up with the kinds of solutions that can only be borne out of collaboration [...] Doing what is good for the community is also good for ourselves. A strong community makes each of us safer and more able to pursue our own goals in life.

ANC, n.d.

In the case of Killorglin in Co. Kerry, Mary played an important role in terms of facilitating the development of a common vision and objectives. She chaired The Gathering Steering Committee, which invited

"one hundred different people around the community involved in different businesses and organizations [to attend] a kind of ideas workshop'. At this meeting, a key issue discussed was that while the famous Puck Fair has been run for more than 400 years and is a key tourist attraction, it was felt that it "dominate[d] our calendar, so people [...] wait[ed] to visit during Puck [...] and the rest of the year [...] merges as a whole range of weekends [...] and there was a need to spread out our calendar a little bit in terms of being ready for tourists."

Thus, the decision was made to "move away from just the Puck Fair" and "rather than having individual events spread across the year, to put them together". Five weekends with separate events were chosen and individual committees ran the events. For example, over the last few years, an Arts festival runs on the bank holiday weekend in June and a Food festival in September. The actions of this SE have resulted in a much clearer vision and strategy for tourism development for the town. Accordingly, Mary played a catalyst role as she saw herself 'as a chair or convenor [and it was important to her that] people felt that they owned the idea'. One key informant said that "all of the parts were there but it needed some spark. It needed a driver".

All of the SEs discussed are visionaries who have played an important catalyst role in developing and implementing a collective vision. In the South African case, the vision is bigger than the local destination, but is a 'lived' ethos demonstrated and passed onto the broader community and visitors through the individual enterprises. Neha continually worked with new and old community members to forge a collective tourism vision in the case of Chatham, and Mary called the meeting that brought people together in the case of Killorglin. Haven-Tang and Jones (2012) note that leaders and followers are mutually important; in each of the cases presented, it is clear that SEs demonstrated leadership roles that resulted in the development and maintenance of a collective vision that is implemented by stakeholders in the destination.

\section{Network architect}

The importance of networks to a rural economy and to rural tourism entrepreneurs (and entrepreneurs in general) has been welldocumented (e.g., Thompson, 2002). Kline and Milburn (2010, p. 330-1) note:

networks that link entrepreneurs to capital, suppliers, employees, partners, and customers are the foundation of the ongoing operation and growth of a venture. Networks should be regional and operate 'in all directions', up and down the supply chain. They should create overlaps among industry sectors and public, private, and non-profit enterprises. And finally, existing networks should be welcoming to new members, whether they are new to a particular industry, or to the community. Particularly useful to rural entrepreneurs are networking/mentoring programs that link established and nascent or growing entrepreneurs.

Often, the SE must not only maintain their own networks, but also create new networks to benefit the larger project or area.

In rural destinations, stakeholders have historically worked within networks related to their particular areas of expertise. Some of these areas are divided by economic sector (e.g., technology, education, retail); yet, others are formed by communities of principles or 'social worlds.' Social worlds are informal and formal associations occurring in our personal and professional lives; within rural development, social worlds are embedded within economic actions and outcomes and business activity is likewise embedded in social relationships and political realms (Clarke Adele, 1991). SEs operate in their own typical and expected professional circles; however, to achieve their goals and to maximize the positive externalities brought on by their organizations, they each intentionally set out to expand their own network, connect existing networks, and/or create new networks. In so doing, they often create social capital.

The website for Angelina's Kitchen boasts of their local farmer partners (http:/ / www.angelinaskitchenonline.com/our-farmers/); over 35 farm operations benefit from the restaurant. Angelina and John have much more than a supplier-vendor relationship, they have become a catalyst for farmers, families, and organizations interested in eating and supporting the mission of healthy food. As a restaurateur, Angelina is continuously building networks for herself and for her constituents; her restaurant serves as a gathering place for a cross-section of the community. She notes: "I network all day long. It's important to work with others. Being open to collaboration and fostering that in others."

Additionally, starting ANC in 2003 was a way to formalize a collective vision "where people increasingly meet their needs locally and sustainably" (ANC, "Mission and Vision", n.d.) that Tami and others had for the community. While tourism was not an explicit direction at the outset, it grew to become a vital part of their outreach and impact and one means for fulfilling their mission (ANC, n.d.). The ANC draws together like-minded people who may not have previously known each other. The offices are located on a rural tract of land in the county that is convenient to the county's largest town. The space allows ANC and partners to run natural resource based initiatives, but also provides a setting for many community-based events, including an annual Pepper Festival, a 5K run, several Do-It-Yourself classes, and sustainability workshops and tours (ANC, n.d.). The land serves as a 'campus' and 'incubator', allowing 
start-up businesses and non-profit initiatives to evolve in a collaborative setting that builds social capital and innovation. Operations are undergirded with a tone of transparency, collaboration, positivity, and fun, but always point in the direction of sustainability and community resilience. Tami leads by providing the setting and tone for these programs and dozens of others to emerge; she consults with dozens of organizations and individuals on their goals and vision, most often effectively weaving them into a common direction for the county and beyond.

Sometimes we dream up our own ideas, like our new Small House Contest. Sometimes a community member comes to us for advice, and a new project grows out of that request for help, like our Climate Change Adaptation Conference for farmers. Sometimes someone has a great idea but needs our support to make it happen, like many of our DIY Sustainability Workshops, or our Fiscal Sponsorship Program that takes fledgling non-profits under our wing to help them get off the ground. And sometimes we hear about something people are doing elsewhere that we think would be a great addition to our own community, like starting our own Pecha Kucha Night series, an idea-sharing slide show event.

ANC, "History of Abundance," n.d.

Similar to ANC in Chatham County, the inaugural FTT certification has attracted entrepreneurs and managers from all over Southern Africa. In the case of the three geographically isolated SEs along the Eastern Cape, their affiliation with FTT provided a common interest that stimulated collaboration. For example, David said "we work quite closely with some of the backpackers in the area and we exchange ideas" (Coffee Shack). The relatively close proximity to other FTT businesses was highlighted by Paul when he said

there is a synergy, there is opportunity to work with other fair trade businesses as there are a cluster of accommodation establishments and fair trade activities in this area of the country and fair trade is certainly trying to facilitate synergies [...] in co-operating with certain inbound tour operators internationally we have a very good relationships with companies who package all the fair trade products into itineraries (Calabash Tours).

Further building on the synergies highlighted between SEs, Dave referred to supporting other FTT businesses based on their collaboration and similar business and social goals. For instance,

we send people to the other FTT businesses that we have seen ourselves [...] we have suggested that we have meetings at locations to check them out and get to know the people [...] its best to see these places in action and then recommend them [...] word of mouth is probably $90 \%$ of our business (Bulungula).

An interest in developing one's network was noted by the informants, as was considering networking from a perspective of scale locally, nationally and internationally, as indicated by Paul.

The emergence of SEs in response to The Gathering strategy (Mottiar, 2016) resulted in many individuals in rural areas coming together to focus on how to attract people to their area. This has resulted in "collaboration and more connection between community groups" and a sense that "we are all trying to achieve the same thing". Brian, who is one of the founders of the new Kfest arts festival in Killorglin, notes the importance of cooperation, stating that "the town is so small that we can't afford not to work together". Brian is an example of a SE who does not run a business in a traditional sense but instead has used entrepreneurial skills to recognize a potential product (festival), establish a committee, and organize an event that attracts approximately 8500 people. In so doing, he has risked his time and reputation. He plays an important role in building partnerships in the town: as a retired teacher, he is well known and has been involved in local drama groups. He was involved with the Puck committee since 1984 and only stopped his involvement when he became Chairman of the community council. In his role now as Chairman of Kfest, he says "we are lucky in Killorglin, we all seem to row in together". For this new festival, he has regularly contacted the chairperson of the Puck festival for advice and he is "good friends with the chairman of Flavour", the other new food festival in the town, and they "often help each other out".

What these cases have identified is the key role that SEs play as network architects. As in discussions of the previously identified roles, the nature of the role differs according to the SE. David in the Eastern Cape highlighted the importance of exchanging ideas, and Dave highlighted the need to learn about the work of others in order to support them. In Chatham, the ANC creates a physical and social space in which cooperation is facilitated and encouraged and Brian in Killorglin uses his personal contacts to create a network to further his social objectives. As network architects, these SEs develop and sustain networks on various scales, as highlighted by Paul (locally, nationally and internationally), and bridge constituents (farmers, residents, tourists, organizations, elected officials). As such, they have an impact across a broad range of stakeholders in the destination and beyond. The networks of the SEs in these cases have provided access to information, people, support, and ideas and have developed social capital in all three destinations.

\section{Discussion and development of framework}

In addition to identifying these three roles sustained by SEs in rural destinations, an objective of the research was to explore how these roles can influence and interact with one another. As Fig. 1 depicts, one SE role can influence other activities and roles within the destination. For example, the visionary role relates to the network architect role. In the case of Neha, the destination vision emerged from a loose network of people who were interested in food and sustainability and once the common vision was established, it was recognized that a formal network was needed in order to implement and sustain this vision. Neha plays the role of opportunist, catalyst, and network architect in her rural area. The connection between the opportunist and visionary roles are evident in the case of Paul, as he identified the opportunity of being part of FTT, which guides his everyday operations, as an opportunity to fulfil his vision for a better South Africa. In the case of Puck Fair networking at the original event organised to discuss the future of tourism in 
the village led to identifying the opportunity of organising more events. These new events were supported by knowledge and information from others in the local network. This shows the complex nature of the roles the SEs play and the way that these different roles can support and also act as triggers for additional roles in the destination.

Fig. 1 encompasses our emerging theory on Social Entrepreneurs in Rural Destinations, emphasizing the three roles of SE as well as some of the ways these roles interconnect. The development of this framework was a key objective of this research as it not only brings clarity to these findings but also acts as a foundation upon which further research can be developed.

Notably, SEs can come from, and focus on, various vantage points within the community. In the case of Neha and Mary, their official position is one at the destination 'level', whereas Angelina, Dave, and David represent individual businesses with a social bottom line. John, Brian, and Tami are SEs in the 'traditional' sense-they are from the non-profit or volunteer sectors and wished to contribute to the community's quality of life by filling a need they perceived. This reflects the earlier discussion of the variety of types of SEs evident in the literature. The inductive approach of this research has facilitated the development of theory, not only relating to specific roles of SEs, but also how these roles inter-relate. The research approach meant that the complexity of their roles was uncovered as the research developed (Ketokivi \& Choi, 2014).

While some of the SEs within this research engaged in all three roles, in other cases they focused on one. For some, the role emerged as a way to address a problem that they identified in the destination (e.g., Tami); for example, to encourage social cohesion (e.g., John and Mary) or alleviate poverty (e.g., Dave and Neha). In others, the role evolved unintentionally as the SEs' activities and involvements morphed into something that addressed a bigger social issue (e.g., Angelina). So while it is clear that SEs do play a role in rural destination development, the roles they play can vary in different situations and destinations. Furthermore, in some cases SEs stimulate action among others to play complementary roles. In the case of Killorglin, Mary developed the collective vision for tourism in the area, but this is now sustained by others who organize specific events and develop networks (e.g., Brian) in order to realize this vision.

Another key finding of the research is the differences that can exist between SEs in terms of motivation. Relative to the lack of specific definition for a SE, it seems that there are a variety of SEs who are motivated by different factors. Some are motivated by the desire to encourage more tourists to the local area (e.g., Mary) specifically as an educational tool to demonstrate what is possible (e.g., Dave) while others are motivated by the desire to address a social problem such as social cohesion or food or environmental awareness (e.g., John and Angelina) and utilize tourism to achieve this objective. Further research is required so that a taxonomy of SEs in tourism is developed to allow us greater insights of this important stakeholder.

\section{Conclusions}

The key finding of our cross-case analysis is that SEs play a vital role in rural destination development. Our paper has demonstrated rural SEs are a significant force in identifying the tourism potential in rural destinations (opportunists), catalyzing a collective vision, and operating as network architects to achieve social objectives, in three destinations, differing in geographical and social contexts. Our findings indicate that rural SEs are likely to be a feature of many destinations worldwide. Thus, it is important that SEs become part of the destination discourse in order to better understand the social objectives of communities transitioning from agriculture to tourism economies.

Our paper identified the roles of SEs as opportunists, catalysts, and network architects. Just as Komppula (2014, p. 361) argued the importance of "innovative, committed and risk-taking entrepreneurs" for destination development, this research reveals that the same can be said for SEs. These roles are vital in the development and functioning of rural tourism destinations in terms of identifying tourism potential, encouraging others to be part of the development activity, and developing networks. Without such actions, the destination and local tourism products would be unlikely to emerge or evolve. Beyond the SE discussion, this finding also highlights the potential for research and discussion around the roles required within destinations and networks to ensure future development, as well as which stakeholders play these roles and why.

There are some limitations of this research to note. Firstly, the research is based on three destinations and nine SEs. While similarities across the cases are evident, a greater scope of research in different situations (e.g., urban, less developed economies, destinations at different points in their lifecycle), different types of SEs (e.g., across a range of ages, years of activity, background) would further enhance our knowledge. Secondly while this research has identified three roles, and the fact that the research was conducted in three different contexts provides a strong underpinning for these findings, it is possible that further studies may highlight additional roles which will add to the theory presented here.

The research highlights several areas deserving of further attention. In particular, future research may focus on questions such as: Do the SE roles change over time? Is the existence of SEs in a destination related to the successful development of the destination? How are SEs situated in urban and rural contexts similar and/or different? Do the SE roles evolve as the destination develops, and if so, how is this transition managed? How do SEs best relate to other stakeholders in tourism destinations? How do they relate to other SEs?

The implications of this research are multifold. Firstly from an academic perspective, our analysis shows that we need to include SEs in our rural tourism lens as a key stakeholder. Secondly, we have begun to generate a theory of rural SE; now it must be tested in other contexts to determine similarities or differences with our findings on rural SEs. From a practical perspective, there are implications in considering how SE's actions may be encouraged or impeded by local policy and other parts of the entrepreneurial ecosystem. In terms of destinations, the analysis of the SEs in this study indicates the extent of influence that these individuals may have, not only in terms of destination development and growth, but in terms of the very fabric of how the local society, community and area operates. Finally in terms of the broader literature, this research highlights that the actions a SE takes to achieve his/her 
social objectives can have secondary effects on other SEs, entrepreneurs, policy makers, local environments and economic sectors, an actuality not considered in the SE literature to date.

The objectives of this paper were to investigate the roles of SEs in rural destination development and build theory in this regard. Our findings revealed the important roles of SEs, in terms of identifying opportunities, acting as a catalyst for action, and being network architects. This has significant consequences for our thinking in terms of rural destination development not only indicating that SEs must be included as key stakeholders and activists who must not be forgotten in our analysis of rural tourism; but also revealing the importance of these roles in terms of initiating ideas, bringing stakeholders together, effecting social change and developing a common vision. Without SEs, rural tourism destinations would be very different places and this research has shaped the foundation of a theory regarding rural SEs that further research can build upon.

\section{References}

Abundance North Carolina (ANC). (n.d.) Mission and vision; what we do; what does "abundance" really mean?. Abundance North Carolina. Retrieved on June 3, 2016 from http://abundancenc.org/.

Ainley, S., \& Kline, C. (2014). Moving beyond positivism: Reflexive collaboration in understanding agritourism across North American boundaries. Current Issues in Tourism, 17(5), 404-413.

Alegre, I., \& Berbegal-Mirabent, J. (2016). Social innovation success factors: Hospitality and tourism social enterprises. International Journal of Contemporary Hospitality, 28(6), 1155-1176.

Altinay, L., Sigala, M., \& Waligo, V. (2016). Social value creation through tourism enterprise. Tourism Management, 54, $404-417$.

Andersson, T., Carlsen, J., \& Getz, D. (2002). Family business goals in the tourism and hospitality sector: Case studies and cross-case analysis from Australia, Canada, and Sweden. Family Business Review, 15, 89-106.

Austin, J., Stevenson, H., \& Wei-Skillern, J. (2006). Social and commercial entrepreneurship: Same, different, or both? Entrepreneurship Theory and Practice, 30(1), 122.

Beritelli, P. (2011). Cooperation among prominent actors in a tourist. Annals of Tourism Research, 38, 607-629.

Boluk, K. (2011). Revealing the discourses white entrepreneurial motivation in Black South Africa. Tourism Planning and Development, 8(2), 199-213.

Boluk, K. (2015). Fair trade tourism. In C. Cater, \& B. Garrod (Eds.). The encyclopedia of sustainable tourism. Wallingford: CABI.

Boluk, K., Cavaliere, C., \& Higgins-Desbiolles, F. (2017). Critical thinking to realize sustainability in tourism systems: Reflecting on the sustainable development goals. Journal of Sustainable Tourism, 25(9), 1201-1204.

Boluk, K., \& Mottiar, Z. (2014). Motivations of social entrepreneurs: Blurring the social contribution and profits dichotomy. Social Enterprise Journal, 10(1), 53-68.

Bosworth, G., \& Farrell, H. (2011). Tourism entrepreneurs in Northumberland. Annals of Tourism Research, 38, 1474-1494.

Central Statistics Office. (2016). Census of population 2016. Preliminary RESULTS http://www.cso.ie/en/releasesandpublications/ep/p-cpr/censusofpopulation2016preliminaryresults/geochan/.

Chatham County.(n.d.).Population andincome information. Chatham County, North Carolina [Government]. Retrieved on June 1, 2016 from http:/ / www.chathamnc. org / Index.aspx?page=26.

Clarke Adele, E. (1991). Social worlds/arenas theory as organizational theory. In D. R. Maines (Ed.). Social organization and social process: Essays in honor of Anselm Strauss. Hawthorne, NY: Walter de Gruyter, Inc.

Covin, J. G., \& Slevin, D. P. (1989). Strategic management of small firms in hostile and benign environments. Strategic Management Journal, $10,75-87$.

Dees, J. G. (1998). The meaning of social entrepreneurship. Stanford: Stanford University Graduate School of Business.

Dollinger, M. J. (2008). Entrepreneurship strategies and resources (4th ed.). Lombard, Illinois: MARSH Publications.

Eisenhardt, K. M. (1989). Building theories from case study research. Academy of Management Review, 14(4), 532-550.

Eisenhardt, K. M., \& Graebner, M. E. (2007). Theory building from cases: Opportunities and challenges. Academy of Management Journal, 50(1), 25-32.

Ergul, M., \& Johnson, C. (2011). Social entrepreneurship in the hospitality and tourism industry: An exploratory approach. Consortium Journal of Hospitality \& Tourism, $16(2), \quad 40-46$.

Gorman, C., \& Mottiar, Z. (2015). Economic recession as a catalyst to increased collaboration in rural tourism. In D. Gursoy, M. Saayman, \& M. Sotiriadis (Eds.). Collaboration in tourism businesses and destinations: A handbook. Bingley, UK: Emerald.

Haven-Tang, C., \& Jones, E. (2012). Local leadership for rural tourism development: A case study of Adventa, Monmouthshire, UK. Tourism Management Perspectives, 4, $28-35$.

Hegarty, C., \& Przezborska, L. (2005). Rural and agri-tourism as a tool for reorganising rural areas in old and new member states? A comparison study of Ireland and Poland. International Journal of Tourism Research, 7, 63-77.

Jaafar, M., \& Rasoolimanesh, S. M. (2015). Tourism growth and entrepreneurship: Empirical analysis of development of rural highlands. Tourism Management Perspectives, 14, 17-24.

Johns, N., \& Mattson, J. (2005). Destination development through entrepreneurship: A comparison of two cases. Tourism Management, $26,605-616$.

Jordan, E. (2015). Planning as a coping response to proposed tourism development. Journal of Travel Research, 54(3), 316-328.

Ketokivi, M., \& Choi, T. (2014). Renaissance of case research as a scientific method. Journal of Operations Management, 32(5), 232-240.

Kimbu, A. N., \& Ngoasong, M. Z. (2016). Women as vectors of social entrepreneurship. Annals of Tourism Research, 60, 63-79.

Kline, C., \& Milburn, L. A. (2010). Ten categories of entrepreneurial climate to encourage rural tourism development. Annals of Leisure Research, 13(1/2), 320-348.

Koh, K., \& Hatten, T. (2002). The tourism entrepreneur: The overlooked player in tourism development studies. International Journal of Hospitality E Tourism Administration, 3, 21-48.

Komppula, R. (2014). Role of individual entrepreneurs in the development of competitiveness for a rural tourism destination - A case study. Tourism Management, 40, $361-371$.

Lashley, C., \& Rowson, B. (2010). Lifestyle businesses: Insights into Blackpool's hotel sector. International Journal of Hospitality Management, $29(3), 511-519$.

Licht, A. N., \& Siegel, J. I. (2006). The social dimensions of entrepreneurship. In M. Casson, \& B. Yeung (Eds.). Oxford handbook of entrepreneurship. University Press.

McGehee, N. G., Knollenberg, W., \& Komoowski, A. (2015). The central role of leadership in rural tourism development: A theoretical framework and case studies. Journal of Sustainable Tourism, 23(8-9), 1277-1297.

Miller, T. L., Grimes, M. G., McMullen, J. S., \& Vogus, T. J. (2012). Venturing for others with heart and head: How compassion encourages social entrepreneurship. Academy of Management Review, 37(4), 616-640.

Mottiar, Z. (2015). The importance of local area as a motivation for cooperation among rural tourism entrepreneur. Tourism Planning and Development, 12, 1-16.

Mottiar, Z. (2016). Exploring the motivations of tourism social entrepreneurs. International Journal of Contemporary Hospitality Management Special Issue on Social Entrepreneurship, 28(6), 1137-1154.

Mottiar, Z., \& Boluk, K. (2017). Understanding how social entrepreneurs fit into the tourism discourse. In P. Sheldon, \& R. Daniele (Eds.). Social entrepreneurship and tourism (pp. 117-134). Cham, Switzerland: Springer.

Mottiar, Z., Quinn, B., \& Ryan, T. (2014). A study of community impacts of the Gathering in Counties Kerry and Westmeath [report]. Failte Ireland.

Nicholls, A. (2010). The legitimacy of social entrepreneurship: Reflexive isomorphism in a pre-paradigmatic field. Entrepreneurship Theory E Practice, 34(4), 611-633.

Okumus, F., Chen, P. J., Barber, N. A., Chan, W., \& Legrand, W. (2016). Guest editorial: Social entrepreneurship in hospitality. International Journal of Contemporary Hospitality Management, 28(6), 1074-1075.

Pavlovich, K. (2003). The evolution and transformation of a tourism destination network: The Waitomo Caves, New Zealand. Tourism Management, $24(2), 203-216$. 
Perrini, F. (2006). Social entrepreneurship domain: Setting boundaries. In F. Perrini (Ed.). The new social entrepreneurship what awaits social entrepreneurial ventures?. Cheltenham, UK: Edward Elgar.

Pittsboro-Siler City Convention and Visitors Bureau (PSCCVB). (n.d.). Explore. Retrieved on June 1, 2016 from http://visitpittsboro.com/activity/explore/. Power, S., Di Domenico, M., \& Miller, G. (2017). The nature of ethical entrepreneurship in tourism. Annals of Tourism Research, 65, 36-48.

Ritchie, J. R. B., \& Crouch, G. I. (2003). The competitive destination: A sustainable tourism perspective. Wallingford, UK: CABI Publishing.

Russell, R., \& Faulkner, B. (2004). Entrepreneurship, chaos and the tourism area lifecycle. Annals of Tourism Research, 31(3), 556-579.

Ryan, T., Mottiar, Z., \& Quinn, B. (2012). The dynamic role of entrepreneurs in destination development. Tourism Planning and Development, 9, 119-131.

Shaw, G., \& Williams, A. M. (1998). Entrepreneurship, small business culture and tourism development. In D. Ioannides, \& K. G. Debbage (Eds.). The economic geography of the tourist industry (pp. 235-255). London: Routledge.

Sheldon, P., \& Daniele, R. (2017). Social entrepreneurship and tourism: Philosophy and practice. Cham, Switzerland: Springer.

Sigala, M. (2016). Learning with the market. International Journal of Contemporary Hospitality Management, 28(6), $1245-1286$.

Stake, R. E. (2005). Multiple case study analysis. New York: Guilford Press.

Thompson, J. L. (2002). The world of the social entrepreneur. International Journal of Public Sector Management, $15(5), 412-431$.

Tinsley, R., \& Lynch, P. A. (2007). Differentiation and tourism destination development: Small business success in a close-knit community. Tourism and Hospitality Research, 8(3), 161-177.

Vasakarla, V. (2008). A study on social entrepreneurship and the characteristics of social entrepreneurs. The Italian Journal of Management Research, 7(4), 32-40. Weiermair, K., Keller, P., Pechlaner, H., \& Go, F. (2010). Innovation and entrepreneurship: Strategies and processes for success in tourism. Schmidt.

Wilson, S., Fesenmaier, D., Fesenmaier, J., \& Van Es, J. (2001). Factors for success in rural tourism development. Journal of Travel Research, $40(2), 132-138$.

Dr. Ziene Mottiar is a lecturer in the School of Hospitality Management and Tourism in Dublin Institute of Technology. Her research interests are Destination development, Tourism entrepreneurs, Social entrepreneurs, and Relationships between entrepreneurs.

Dr. Karla Boluk is an Assistant Professor in the Department of Recreation and Leisure Studies at the University of Waterloo. Her research interests include Ethical consumption, Fair trade, Corporate social responsibility, and Social entrepreneurship.

Dr. Carol Kline is an Associate Professor of Hospitality and Tourism Management at Appalachian State University in the Department of Management. Her professional interests focus on foodie segmentation, craft beverages, agritourism, wildlife-based tourism, animal welfare in tourism, and tourism entrepreneurship. 